\title{
Distribution Characteristic of Soil Organic Carbon Fraction in Different Types of Wetland in Hongze Lake of China
}

\author{
Yan $\mathrm{Lu}^{1,2}$ and Hongwen $\mathrm{Xu}{ }^{1}$ \\ ${ }^{1}$ School of Urban and Environmental Science, Huaiyin Normal University, Huaian 223300, China \\ ${ }^{2}$ Jiangsu Key Laboratory for Eco-Agricultural Biotechnology around Hongze Lake, Huaian 223300, China \\ Correspondence should be addressed to Hongwen Xu; hongwen_xu@163.com
}

Received 10 May 2014; Accepted 13 May 2014; Published 22 May 2014

Academic Editor: Hongbo Shao

Copyright (c) $2014 \mathrm{Y}$. Lu and H. Xu. This is an open access article distributed under the Creative Commons Attribution License, which permits unrestricted use, distribution, and reproduction in any medium, provided the original work is properly cited.

\begin{abstract}
Soil organic carbon fractions included microbial biomass carbon (MBC), dissolved organic carbon (DOC), and labile organic carbon (LOC), which was investigated over a $0-20 \mathrm{~cm}$ depth profile in three types of wetland in Hongze Lake of China. Their ecoenvironmental effect and the relationships with soil organic carbon (SOC) were analyzed in present experiment. The results showed that both active and SOC contents were in order reduced by estuarine wetland, flood plain, and out-of-lake wetland. Pearson correlative analysis indicated that $\mathrm{MBC}$ and $\mathrm{DOC}$ were positively related to SOC. The lowest ratios of MBC and DOC to SOC in the estuarine wetland suggested that the turnover rate of microbial active carbon pool was fairly low in this kind of wetland. Our results showed that estuarine wetland had a strong carbon sink function, which played important role in reducing greenhouse gas emissions; besides, changes of water condition might affect the accumulation and decomposition of organic carbon in the wetland soils.
\end{abstract}

\section{Introduction}

Wetland played a key role in the global cycles of carbon, which had important function in the global carbon balance and climate change mitigation [1-3]. Carbon cycle process in different types of wetland could provide basis for further understanding of the mechanism of carbon sources and sinks in terrestrial ecosystem [4-6]. Decrease of carbon storage and vegetation biomass in wetland soils might release more carbon into atmosphere, thus causing the increase of atmospheric carbon dioxide concentration [7-10]. Meanwhile, global warming could accelerate decomposition of soil organic matter and release of carbon into atmosphere, which would further strengthen the trend of global warming $[11,12]$. Original alteration in soil organic carbon pool of wetland occurred mainly on the part easily to be decomposed and mineralized, that is, activated carbon [13]. Soil activated carbon was referred to the part of the organic carbon with poor stability and higher activity for plants and soil microorganisms [14]. Soil microbial biomass carbon (MBC) and dissolved organic carbon (DOC) were important characteristic indicators for expressing the activity of active soil organic carbon pool [15]. Although active organic carbon was just a very small part of total carbon, its sizes and turnover rates were of great importance to the content and recycling of soil available nutrients, and it was directly related to greenhouse gas emissions [16]. Therefore, exploring the changes of soil active organic carbon in different types of wetland was helpful in achieving deep understanding of the characteristics of wetland soil organic carbon and the response to climate change.

Hongze Lake $\left(33^{\circ} 06^{\prime} \mathrm{N} \sim 33^{\circ} 40^{\prime} \mathrm{N}, 118^{\circ} 10^{\prime} \mathrm{E} \sim 118^{\circ} 55^{\prime} \mathrm{E}\right)$ is the fourth largest fresh water lake in China. It is located in the northwest of Jiangsu province, and its water area is $1597 \mathrm{~km}^{2}$. The lake and the surrounding area have composed a relatively intact inland wetland as typical lake wetland of China. Differences might exist in soil carbon pool due to various hydrological conditions and vegetation for kinds of wetland. Although researches on soil carbon in wetland have been well documented, limited systematic investigations focus on different types of natural lakes wetland soil carbon and their ecological environment effect. In order to study the distribution characteristics of different types of wetland soil active organic carbon about Hongze Lake Wetland, MBC, 


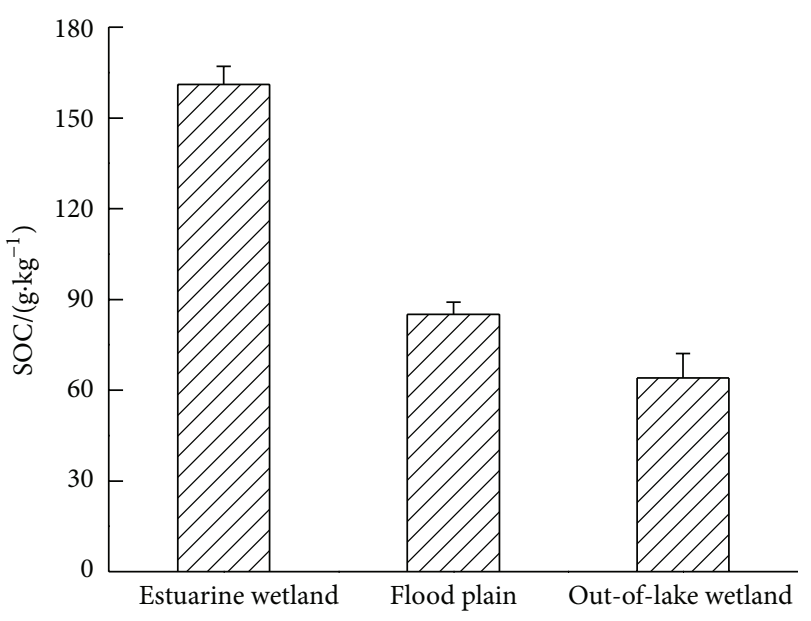

Figure 1: Changes of SOC content under different types of wetland in Hongze Lake of China.

soluble organic carbon (SOC), DOC, labile organic carbon (LOC), and their ecological environment effects were studied in the present experiment.

The objective of this research was to study the role which different types of wetland soil active organic carbon played in the biogeochemical cycle and thereby to provide a theoretical basis for a good deal of insight into biogeochemical cycle mechanism of wetland soil carbon.

\section{Material and Methods}

2.1. Experimental Design. The experimental site is located at Hongze Lake, China. Three sample plots were selected in south, east, and west bank of Hongze Lake Wetland (representing Estuary wetland, flood plain, and out of lake wetland, separately). The research sample point of three types of wetlands was chosen in the middle of April 2012, and the indicators related to surface vegetation distribution and hydrological conditions were observed and recorded. Soil of $0-20 \mathrm{~cm}$ depth was collected into a sterile bag by using the multipoint-mix-sampling method; the soil samples were taken back to the laboratory quickly and divided into two parts. One part was refrigerated under $4^{\circ} \mathrm{C}$, which was used to measure soil water content, DOC, and MBC. Another part of the soil sample was just put in the air and taken through a $0.25 \mathrm{~mm}$ sieve after being dried and grinded. The latter part was applied to the analysis of SOC and LOC.

2.2. Measurements. Soil organic carbon was determined by taking potassium dichromate volumetric method. MBC was measured using chloroform fumigation- $\mathrm{K}_{2} \mathrm{SO}_{4}$ extraction method. TOC instrument was used to determine DOC concentration. Content of LOC estimation was performed according to the method of potassium permanganate oxidation.

2.3. Data Analysis. The data was analyzed by one-way analysis of variance (ANOVA) followed by Duncan's test at 0.05

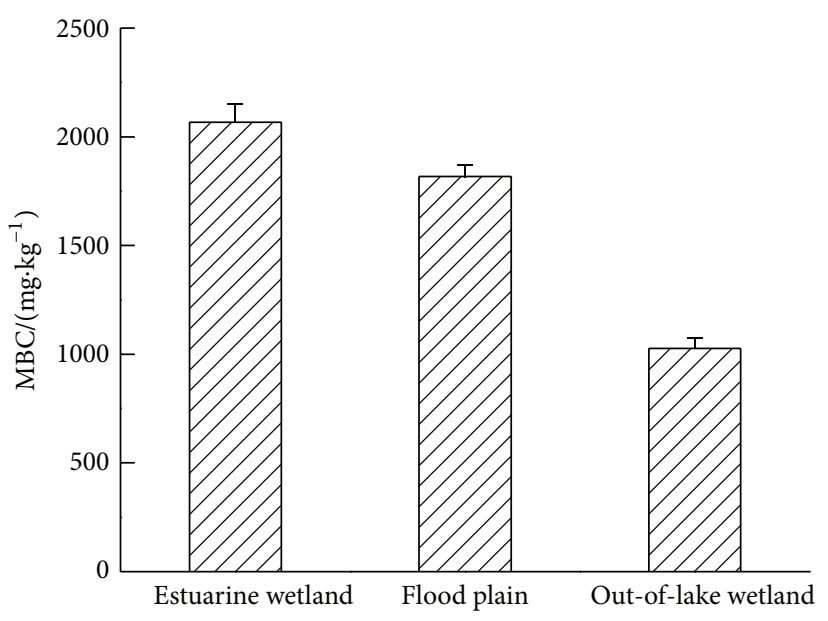

FIgURE 2: Changes of MBC content under different types of wetland in Hongze Lake of China.

significance level to compare the means using SPSS 16.0 for Windows.

\section{Results}

3.1. Distribution Characteristics of Soluble Organic Carbon. Soil was considered as a carbon source and sink; if organic matter content in soil reduced by one percent, atmospheric $\mathrm{CO}_{2}$ concentration would increase by $5 \mathrm{mg} \cdot \mathrm{m}^{-3}$. The difference between soil texture and number of vegetation types would lead to variety of input and output of organic matter and causing differences in SOC content. Figure 1 showed the change trend of SOC content at $0-20 \mathrm{~cm}$ depth in three kinds of typical natural wetlands. It also could be seen that the SOC content in the estuary wetland had the peak value with $161.67 \mathrm{~g} \cdot \mathrm{kg}^{-1}$, which was significantly higher than that of two other types of wetlands. SOC content of wetland soil depended largely on the circulation and decomposition rate of vegetation annually. Estuary wetland was under flooded condition all the year round, resulting in the slow decomposition of organic residue, which caused accumulating of SOC. A seasonal depletion that occurred in flood plain, aerobic microorganisms, and soil enzyme hydrolysis could bring about higher decomposition of organic matter than estuarine wetland when it was not flooding [17]. However, ventilation condition in flood plain was relatively poor compared with out-of-lake wetland. Therefore, the organic carbon content of flood plain was fairly higher than the latter.

\subsection{Distribution Characteristics of Microbial Biomass Carbon.} $\mathrm{MBC}$ was referred to the internal carbon in live bacteria, fungi, algae, and soil animals whose volume was less than 5$105 \mu \mathrm{m}^{3}$; it accounted for only a small portion of total carbon in soil; however, it was the most active section in soil organic matter [18]. Besides, it was taken on as the main driving force for decomposition of nutrient pool [19-21]. As an important source of soil nutrients, it correlated closely with cycling of the nutrients such as $\mathrm{C}, \mathrm{N}, \mathrm{P}$, and $\mathrm{S}$ [22]. Changes of MBC 


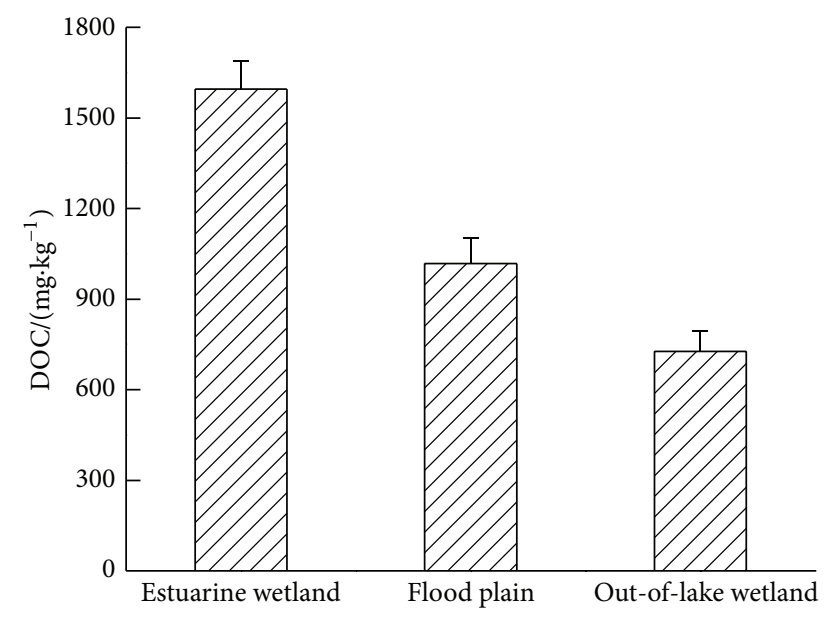

Figure 3: Changes of DOC content under different types of wetland in Hongze Lake of China.

were in accordance with SOC, and significant difference of $\mathrm{MBC}$ content in soil of three different types of wetland was found in present experiment (Figure 2) $(P<0.01)$. Positive relationship was found between soil $\mathrm{MBC}$ content and SOC content of three kinds of wetland $(r=0.823, P<0.05)$. The ratio of $\mathrm{MBC}$ and SOC reflected the conversion efficiency from the organic matter into $\mathrm{MBC}$, which could imply the turnover rate of biologically active soil organic carbon pool. The specific value of $\mathrm{MBC} / \mathrm{SOC}$ of estuary wetland, flood plain, and out-of-lake wetland was $1.28 \%, 2.12 \%$, and $1.6 \%$, which suggested that flooded condition could inhibit aerobic microbial activity.

3.3. Distribution Characteristics of Dissolved Organic Carbon. DOC mainly originated from the recent humus of plant litter and soil organic matter, which included a series of organic matter from simple organic acids to the complex of macromolecular substances, such as humic acid and fulvic acid [23-25]. And it was taken as organic carbon source directed using for soil microbes, and affecting the transformation, migration, and degradation of soil organics and inorganics [26-28]. The formation, migration, and transformation of DOC in the wetland had important influence on soil carbon flux [29]. Similar changing trend in DOC and MBC in 0$20 \mathrm{~cm}$ of soil appeared in Figure 3, and ANOVA analysis showed that the DOC content of estuarine wetland was significantly higher than that of flood plain and out-of-lake wetland $(P<0.01)$. This was due to the flooded condition of estuary wetland, which could improve the dissolution of soil organic carbon and the dispersion of soil aggregate [30, 31]. Pearson correlation suggested that it was significantly and positively related to DOC and SOC of the three different types of wetland soil $(r=0.872, P<0.01)$, which indicated that SOC was the main source of DOC. The ratio of DOC to SOC of estuary wetland, flood plain, and out-of-lake wetland was $0.09 \%, 1.19 \%$, and $1.12 \%$ individually. The lowest proportion that occurred in estuarine wetland would declare the lower

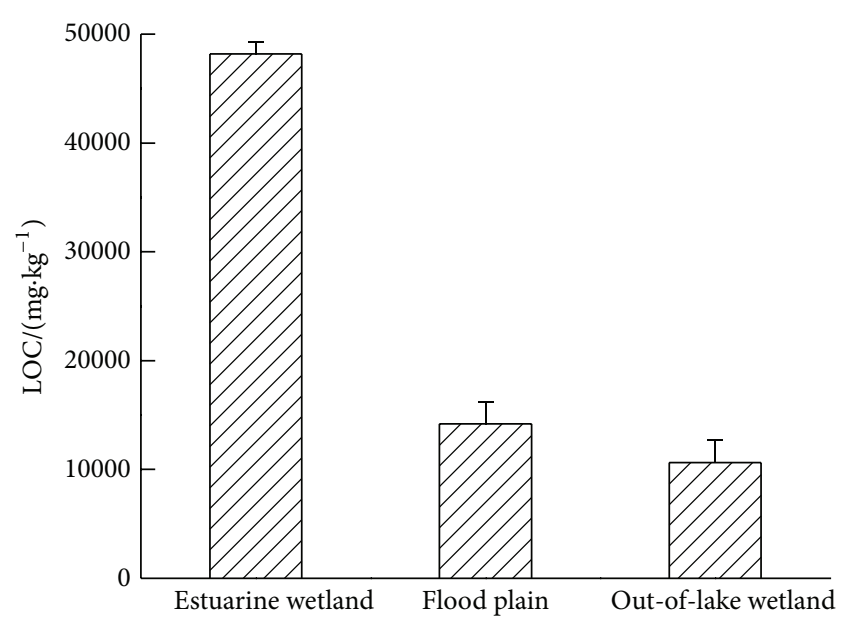

FIgURE 4: Changes of LOC content under different types of wetland in Hongze Lake of China.

turnover rate of biological active soil organic carbon pool in estuary wetland.

3.4. Distribution Characteristics of Labile Organic Carbon. Soil LOC content and the ratio of LOC to SOC were the indexes to reflect the stability of soil carbon. And the two indexes of estuarine wetland soil were significantly higher than that of flood plain and out-of-lake wetland (Figure 4). Positively significant correlation between LOC and SOC in different types of wetland soil was found in present experiment $(r=0.952, P<0.01)$; thus, the quantity of SOC could determine the abundance of LOC. The higher the proportion of LOC/SOC was, the worse the stability was. Special hydrological conditions of wetland would make the anaerobic environment; when hydrological conditions changed from anaerobic into aerobic environment, huge LOC would be decomposed and consumed by microbes [32, 33].

\section{Conclusions}

From this study, we concluded that estuarine wetland had fairly important environmental function in the greenhouse gas emissions reduction and the climate change mitigation. And we supported the speculation that variation in water condition would have a real impact on the accumulation and decomposition of organic carbon in the wetland soils.

\section{Conflict of Interests}

The authors declare that there is no conflict of interests regarding the publication of this paper.

\section{Acknowledgments}

This work was supported by the National Natural Science Foundation of China (41201559; 41301314) and the Natural Science Foundation of Jiangsu province (BK2011412). 


\section{References}

[1] N. Saintilan, K. Rogers, D. Mazumder, and C. Woodroffe, "Allochthonous and autochthonous contributions to carbon accumulation and carbon store in southeastern Australian coastal wetlands. Estuarine," Coastal and Shelf Science, vol. 128, no. 10, pp. 84-92, 2014.

[2] J. Q. Gao, G. C. Lei, X. W. Zhang, and G. X. Wang, "Can $\delta^{13} \mathrm{C}$ abundance, water-soluble carbon, and light fraction carbon be potential indicators of soil organic carbon dynamics in Zoigê wetland?" Catena, vol. 119, no. 8, pp. 21-27, 2014.

[3] M. Liu, Z. J. Zhang, Q. He, H. Wang, and X. Li, "Jonathan Schoer Exogenous phosphorus inputs alter complexity of soil-dissolved organic carbon in agricultural riparian wetlands," Chemosphere, vol. 95, pp. 572-580, 2014.

[4] A. C. Barbera, M. Borin, A. Ioppolo, G. L. Cirelli, and C. Maucieri, "Carbon dioxide emissions from horizontal subsurface constructed wetlands in the Mediterranean Basin," Ecological Engineering, vol. 64, no. 3, pp. 57-61, 2014.

[5] W. Yang, H. Zhao, X. L. Chen, S. L. Yin, X. Y. Chen, and S. Q. An, "Consequences of short-term $\mathrm{C}_{4}$ plant Spartina alterniflora invasions for soil organic carbon dynamics in a coastal wetland of Eastern China," Ecological Engineering A, vol. 61, no. 12, pp. 50-57, 2013.

[6] J. Wang, C. Song, X. Wang, and Y. Song, "Changes in labile soil organic carbon fractions in wetland ecosystems along a latitudinal gradient in Northeast China," Catena, vol. 96, pp. 8389, 2012.

[7] Q. S. Lu, Z. Q. Gao, Z. H. Zhao, J. C. Ning, and X. L. Bi, "Dynamics of wetlands and their effects on carbon emissions in China coastal region-case study in Bohai Economic Rim," Ocean \& Coastal Management, vol. 87, no. 1, pp. 61-67, 2014.

[8] L. Huo, Z. Chen, Y. Zou, X. Lu, J. Guo, and X. Tang, "Effect of Zoige alpine wetland degradation on the density and fractions of soil organic carbon," Ecological Engineering, vol. 51, pp. 287295, 2013.

[9] X. Yang, W. Ren, B. Sun, and S. Zhang, "Effects of contrasting soil management regimes on total and labile soil organic carbon fractions in a loess soil in China," Geoderma, vol. 177-178, pp. 49-56, 2012.

[10] J. Beringer, S. J. Livesley, J. Randle, and L. B. Hutley, "Carbon dioxide fluxes dominate the greenhouse gas exchanges of a seasonal wetland in the wet-dry tropics of northern Australia," Agricultural and Forest Meteorology, vol.182-183, no. 12, pp. 239$247,2013$.

[11] D. S. Jenkinson, D. E. Adams, and A. Wild, "Model estimates of $\mathrm{CO}_{2}$ emissions from soil in response to global warming," Nature, vol. 351, no. 6324, pp. 304-306, 1991.

[12] L. X. Yang and J. J. Pan, "Progress in the study of measurements of soil active organic carbon pool," Chinese Journal of Soil Science, vol. 35, no. 4, pp. 502-506, 2004 (Chinese).

[13] J. Q. Gao, H. Ouyang, and J. H. Bai, "Vertical distribution characteristics of soil labile organic carbon in Ruoergai wetland," Journal of Soil and Water Conservation, vol. 20, no. 1, pp. 7679, 2006 (Chinese).

[14] H. Shen, Z. Y. Cao, and Z. Y. Hu, "Characteristics and ecological effects of the active organic carbon in soil," Chinese Journal of Ecology, vol. 18, no. 3, pp. 32-38, 1999 (Chinese).

[15] B. C. Liang, M. Schnitzer, C. M. Monreal, A. F. MacKenzie, P. R. Voroney, and R. P. Beyaert, "Management-induced change in labile soil organic matter under continuous corn in eastern
Canadian soils," Biology and Fertility of Soils, vol. 26, no. 2, pp. 88-94, 1998.

[16] J. Z. Ni, J. M. Xu, and Z. M. Xie, “The size and characterization of biologically active organic carbon pool in soils," Plant Nutrition and Fertilizer Science, vol. 7, no. 1, pp. 56-63, 2001 (Chinese).

[17] Q. Liang, R. T. Gao, B. D. Xi, Y. Zhang, and H. Zhang, "Longterm effects of irrigation using water from the river receiving treated industrial wastewater on soil organic carbon fractions and enzyme activities," Agricultural Water Management, vol. 135, no. 3, pp. 100-108, 2014.

[18] T. H. Anderson and K. H. Domsch, "Application of ecophysiological quotients $\left(\mathrm{qCO}_{2}\right.$ and $\left.\mathrm{qD}\right)$ on microbial biomasses from soils of different cropping histories," Soil Biology and Biochemistry, vol. 22, no. 2, pp. 251-255, 1990.

[19] Z. H. Shang, Q. S. Feng, G. L. Wu, G. H. Ren, and R. J. Long, "Grasslandification has significant impacts on soil carbon, nitrogen and phosphorus of alpine wetlands on the Tibetan Plateau," Ecological Engineering, vol. 58, no. 2, pp. 170-179, 2013.

[20] X. Wang, C. Song, X. Sun, J. Wang, X. Zhang, and R. Mao, "Soil carbon and nitrogen across wetland types in discontinuous permafrost zone of the Xiao Xing'an Mountains, northeastern China," Catena, vol. 101, pp. 31-37, 2013.

[21] X. Ye, A. J. Wang, and J. Chen, "Temporal-spatial variation and source analysis of carbon and nitrogen in a tidal wetland of Luoyuan Bay," Acta Ecologica Sinica, vol. 33, no. 3, pp. 150-157, 2013.

[22] Y. Lu, H. W. Xu, and C. C. Song, "Effects of plants on $\mathrm{N}_{2} \mathrm{O}$ emission in freshwater marsh ecosystem," Journal of Food, Agriculture and Environment, vol. 10, no. 1, pp. 662-666, 2012.

[23] C. Mu, H. Lu, B. Wang, X. Bao, and W. Cui, "Short-term effects of harvesting on carbon storage of boreal Larix gmelinii-Carex schmidtii forested wetlands in Daxing'anling, northeast China," Forest Ecology and Management, vol. 293, no. 4, pp. 140-148, 2013.

[24] H. Wu, D. P. Batzer, X. Yan, X. Lu, and D. Wu, "Contributions of ant mounds to soil carbon and nitrogen pools in a marsh wetland of Northeastern China," Applied Soil Ecology, vol. 70, pp. 9-15, 2013.

[25] J. N. Sun, B. C. Wang, G. Xu, and H. B. Shao, "Effects of wheat straw biochar on carbon mineralization and guidance for large-scale soil quality improvement in the coastal wetland," Ecological Engineering, vol. 62, no. 1, pp. 43-47, 2014.

[26] J. R. Burford and J. M. Bremner, "Relationships between the denitrification capacities of soils and total, water-soluble and readily decomposable soil organic matter," Soil Biology and Biochemistry, vol. 7, no. 6, pp. 389-394, 1975.

[27] J. Z. Ni, J. M. Xu, and Z. M. Xie, "Advances in soil water-soluble organic carbon research," Ecology and Environment, vol. 12, no. 1, pp. 71-75, 2003 (Chinese).

[28] M. M. Wander, S. J. Traina, B. R. Stinner, and S. E. Peters, "Organic and conventional management effects on biologically active soil organic matter pools," Soil Science Society of America Journal, vol. 58, no. 4, pp. 1130-1139, 1994.

[29] C. C. Song, Y. Y. Wang, and B. X. Yan, "The changes of the soil hydrothermal condition and the dynamics of $\mathrm{C}, \mathrm{N}$ after the mire tillage," Environmental Science, vol. 25, no. 3, pp. 168-172, 2004 (Chinese).

[30] Z. P. Li, T. L. Zhang, and B. Y. Chen, "Dynamics of soluble organic carbon and its relation to mineralization of soil organic carbon," Acta Pedologica Sinica, vol. 41, no. 4, pp. 544-552, 2004 (Chinese). 
[31] A. O. Olaleye, T. Nkheloane, R. Mating et al., "Wetlands in Khalong-la-Lithunya catchment in Lesotho: soil organic carbon contents, vegetation isotopic signatures and hydrochemistry," Catena, vol. 115, no. 4, pp. 71-78, 2014.

[32] Y. Zhang, Y. Li, L. Wang et al., "Soil microbiological variability under different successional stages of the Chongming Dongtan wetland and its effect on soil organic carbon storage," Ecological Engineering, vol. 52, pp. 308-315, 2013.

[33] Y. Hu, L. Wang, Y. S. Tang et al., "Variability in soil microbial community and activity between coastal and riparian wetlands in the Yangtze River estuary-Potential impacts on carbon sequestration," Soil Biology and Biochemistry, vol. 70, no. 1, pp. 221-228, 2014. 

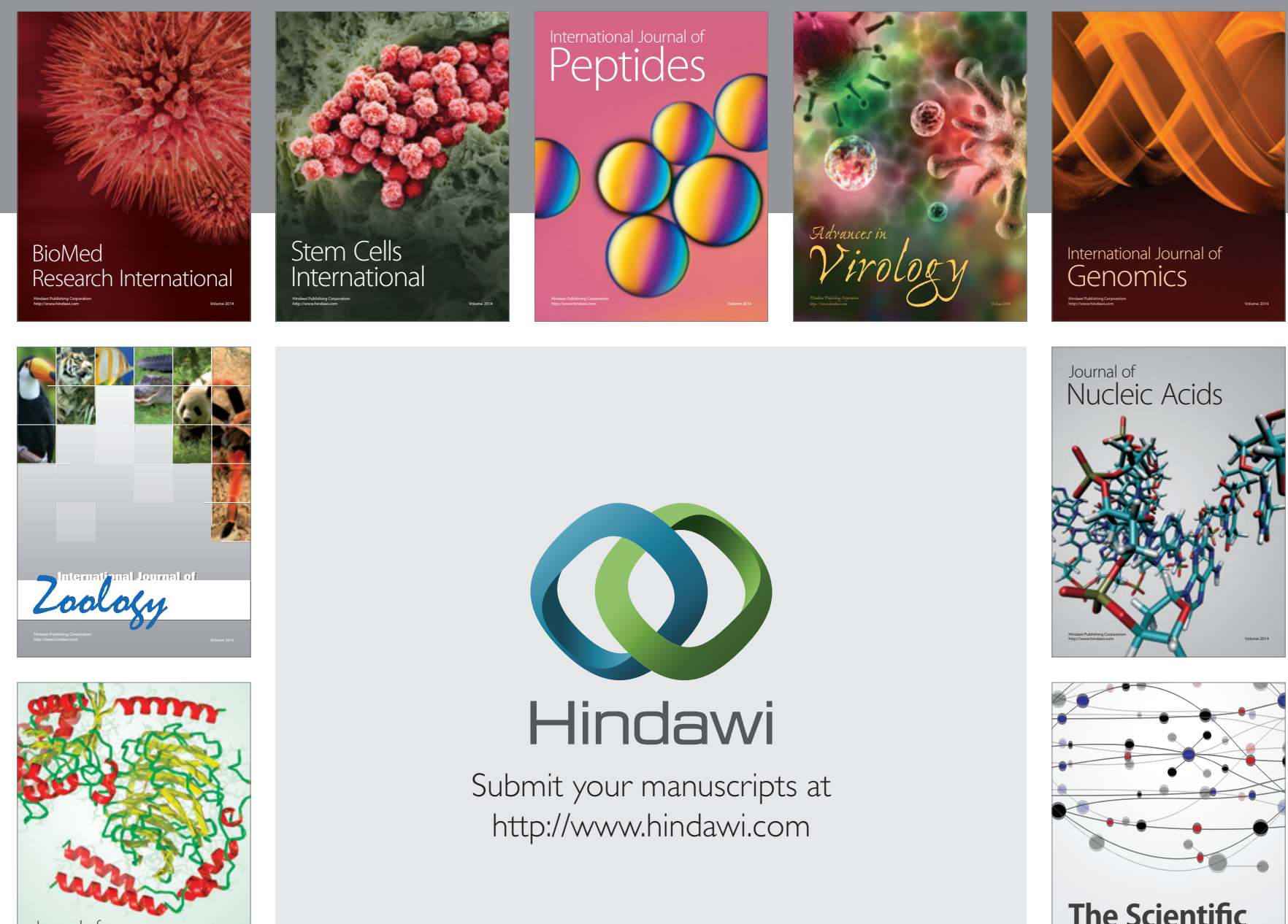

Submit your manuscripts at

http://www.hindawi.com

Journal of
Signal Transduction
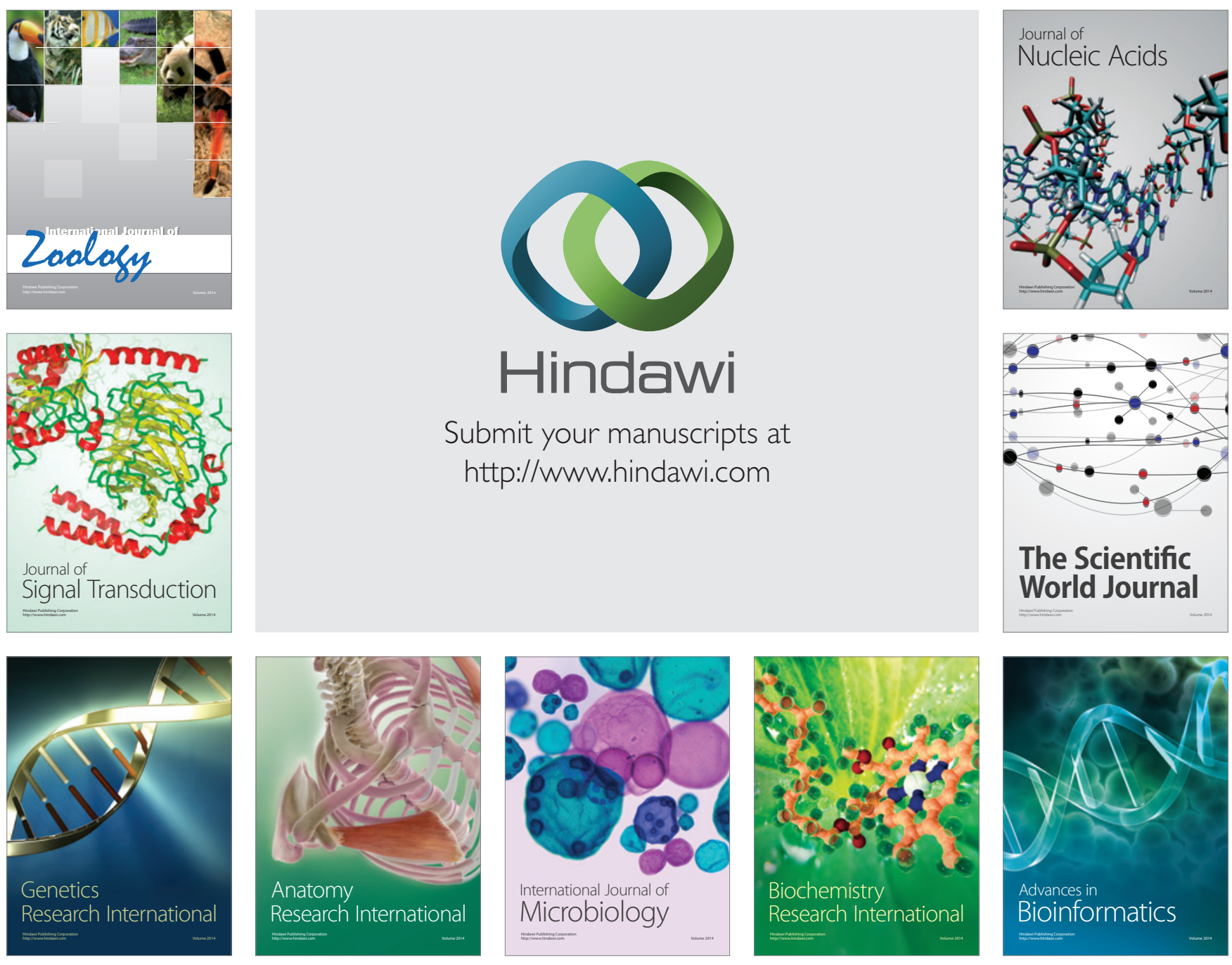

The Scientific World Journal
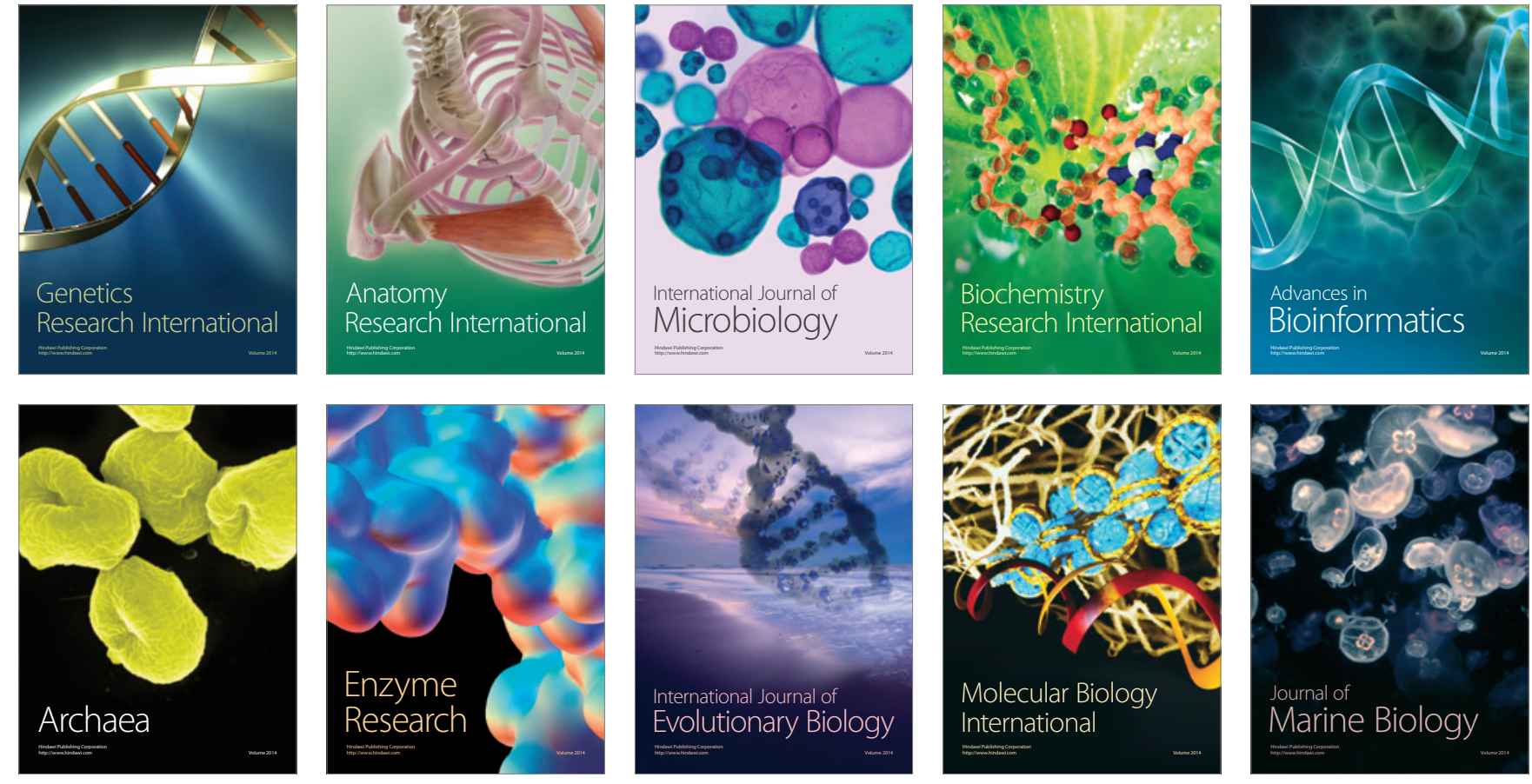